\title{
Outcome of acute lower respiratory tract infection in infants: preliminary report of seven-year follow-up study
}

\author{
JACQUELINE Y Q MOK, HAMISH SIMPSON
}

\begin{abstract}
Seven years after admission to hospital for acute lower respiratory tract infection in infancy 200 children and their matched controls were assessed for respiratory state and epidemiological characteristics. The index group comprised 100 cases where respiratory syncytial virus infection had been responsible for the index illness (group 1) and 100 cases in whom this organism had not been found (group 2).

There were no differences between index and control groups in birth weight or gestational age but fewer index cases were breast fed. Social indices such as class distribution and family size were more favourable in controls, though housing standards and maternal smoking habits were similar in the two groups. The prevalence of subsequent respiratory symptoms-cough, wheeze, nasal discharge, and hearing difficulties-was greater in index cases as was absence from school and family doctor consultation for respiratory illness. Bronchitis and asthma were significantly more common in the index group. Impaired ventilatory function and bronchial hyperreactivity were found in index cases when compared with controls. No differences in clinical characteristics and outcome were found in the two groups of index cases.

The question whether lung "damage" during lower respiratory tract infection predisposes to subsequent respiratory problems or whether certain infants are more vulnerable than others to respiratory illnesses (including lower respiratory tract infection) from the outset is unanswered.
\end{abstract}

Department of Child Life and Health, University of Edinburgh, Edinburgh EH9 1UW

JACQUELINE Y Q MOK, MRCP, DCH, research fellow (present appointment: trainee clinical medical officer, Lothian Health Board, Edinburgh)

Royal Hospital for Sick Children, Edinburgh EH9 1UW

HAMISH SIMPSON, MD, FRCP, consultant paediatrician (present appointment: professor of child health, University of Leicester)

\section{Introduction}

Epidemiological studies of the origins of chronic bronchitis in adults have identified important environmental factors which act singly or in combination. In adults, the dominant effects of smoking and occupational exposure to pollutants on the prevalence of respiratory symptoms make it difficult to assess the relative contribution of other factors. The results of studies in young children are easier to interpret as the effects of "active" smoking and occupation do not have to be considered. Moreover, an assessment of familial factors that may be relevant to the development of respiratory disease is facilitated by recording contemporary data on parents and siblings.

Social and family factors, ${ }^{12}$ housing conditions, ${ }^{3}$ air pollution, ${ }^{4-6}$ and "passive" smoking ${ }^{7-9}$ increase the likelihood of respiratory illness in children. Studies of the clinical course of childhood respiratory infection $s^{10-12}$ suggest that the occurrence of respiratory illnesses in adult life is also increased. In such studies it is difficult to obtain accurate clinical and aetiological information about early childhood respiratory illnesses in large numbers of patients. Even when the clinical illness is carefully defined or the causative agent known, follow-up studies give conflicting results concerning subsequent symptoms such as wheeze.

The prevalence of recurrent wheezing after acute bronchiolitis (the commonest lower respiratory tract infection in infancy) has been reported to vary from $6 \%$ to $50 \%{ }^{13-15}$ and in one study ${ }^{16}$ where respiratory syncytial virus was identified as the cause of bronchiolitis $56 \%$ of children wheezed recurrently during the preschool years. Varying criteria for the selection of patients, paucity of controls, and differing periods of follow-up probably account for the differences in estimates of prevalence. Moreover, virological findings during index illnesses are rarely given. We have therefore conducted a case-control study of 200 children who had been admitted to hospital for acute lower respiratory tract infections in infancy seven years before and in whom the results of virological studies were known. We assessed the prevalence and severity of subsequent respiratory symptoms and established respiratory disorders (bronchitis, asthma), lung function, and the possible influence of social and environmental factors. As respiratory syncytial virus is the commonest respiratory pathogen in infancy in the United Kingdom ${ }^{17}$ the index group was selected to include 100 cases with proved respiratory 
syncytial virus infection and 100 cases in whom this organism was not identified.

\section{Subjects and methods}

\section{SUBJECTS}

The case records of 376 children under 1 year of age admitted to the Royal Hospital for Sick Children in Edinburgh with bronchitis, bronchiolitis, or pneumonia during the winter periods 1971-2, 19723 , and 1973-4, were traced and analysed. Virological studies had been performed in 340 during their index illnesses. Nasal and throat swabs were obtained during the first winter period, and nasopharyngeal secretions during the subsequent periods within a day of admission to hospital. Respiratory syncytial virus infection was diagnosed on the basis of immunofluorescent or culture techniques. No attempt was made to obtain paired sera in these infants. Respiratory syncytial virus was the infecting agent in 149 ; in the remaining 191 respiratory syncytial virus infection was not confirmed. Those with and without respiratory syncytial virus were then grouped separately for each winter period according to age (to within three months) at the time of the illness and equal numbers of "age matched" children with and without respiratory syncytial virus were selected at random from each group. A total of 115 children with and 115 without respiratory syncytial virus were thus chosen as possible index cases for the study.

Letters requesting co-operation were sent to parents. Forty-two children (18 with and 24 without respiratory syncytial virus) had moved from the area and were replaced by children from the original list of those eligible for study. The parents of 216 children were finally contacted and 200 favourable replies were received (100 with and 100 without respiratory syncytial virus), thereby completing the index groups.

Each control was chosen from the same class in the same school as the corresponding index case and matched for sex, age (to within three months), and, where possible, height. None of the control children had had a respiratory illness in infancy that had necessitated admission to hospital.

\section{METHODS}

The children and their parent(s) attended the respiratory function laboratory at the Royal Hospital for Sick Children. The accompanying parent was interviewed by one of us (JM) and a detailed questionnaire completed. Each child was then examined fully and tests of respiratory function performed.

Total respiratory resistance $\left(\mathbf{R}_{\mathrm{T}}\right)$ was measured with the patient standing by using a modification of the forced oscillation technique. ${ }^{18}$ The subject wore a nose clip and breathed quietly through a disposable mouthpiece for one or two minutes. A six cycle/second oscillation at a preselected peak-to-peak pressure of $2 \mathrm{~cm}$ water was then superimposed on the normal respiratory flow pattern with the operator supporting the subject's cheeks. $\mathbf{R}_{\mathrm{T}}$ defined by the ratio of pressure to flow was measured during expiration.

A Wright peak flow meter ${ }^{19}$ measured peak expiratory flow rate (PEFR). The best of three attempts was accepted and reported as a percentage of the predicted normal value for both boys and girls. ${ }^{20}$

An electronic spirometer (Spirotron, Draeger Ltd) measured forced expiratory volume in one second $\left(F E V_{1}\right)$ and forced vital capacity (FVC). Results were displayed digitally and recorded graphically. The highest values from three forced expirations were accepted. The forced expiratory volume in 0.75 second $\left(\mathrm{FEV}_{0.75}\right)$ and the forced expiratory flow in the middle half of the expired volume $\left(\mathrm{FEF}_{25-75 \%}\right)$ were calculated from the spirogram obtained and related to normal values. ${ }^{20}$

Maximum expiratory flow volume (MEFV) curves breathing air and an $80 \%$ helium and $20 \%$ oxygen mixture were obtained as described. ${ }^{21}$ MEFV curves from index cases and matched controls from the third winter period (1973-4) were photographed and analysed manually. $\mathrm{FEV}_{1}, \mathrm{FVC}$, maximal flow at $50 \%$ of vital capacity and at $25 \%$ vital capacity were derived from the MEFV curves. The changes in flow breathing helium and oxygen were obtained. Results were expressed as a percentage of predicted values for height and sex.

The subject then ran continuously on a treadmill (Quinton Ltd) for six minutes at a speed of about $5 \mathrm{~km} / \mathrm{h}$ and on a slope of $15 \%$ wearing a nose clip. The electrocardiogram was displayed continuously and in each case heart rate was maintained at above 160 beats/ min. PEFR was measured before, during (at two and four minutes without interrupting the test), and after exercise $(0,2,5,10,15$, and 20 minutes). Room temperatures ranged from $19^{\circ} \mathrm{C}$ to $23^{\circ} \mathrm{C}$ during the study and relative humidity from $30 \%$ to $50 \%$. The maximum rise in PEFR during exercise and maximum fall after exercise were calculated as percentage of the resting PEFR.

After each child's visit general practitioners were contacted and asked to confirm the history obtained from the parents. Medical records were scrutinised with the general practitioner's consent whenever there was a history of respiratory problems or apparen conflict between parental and medical information. More than twothirds of the medical records of the children were finally reviewed and relevant information coded.

\section{STATISTICAL ANALYSIS}

For matched pairs, continuous data were analysed using Student's $t$ test while analysis of categorical or qualitative data was performed by using McNemar's test. ${ }^{22}$ Continuous data from unmatched pairs were analysed by using Student's unpaired $t$ test or the Wilcoxon ranked signs test, the $\chi^{2}$ being used for qualitative data.

\section{Results}

\section{CLINICAL}

The mean age of patients at the time of hospital admission was 4.3 2.9 months. Of those recalled for study, 45 had bronchitis ( 15 with and 30 without respiratory syncytial virus), 104 bronchiolitis ( 56 with and 48 without), and 51 pneumonia ( 29 with and 22 without) during their index illnesses. Viruses other than respiratory syncytial virus were isolated in 17 cases. Double infection with rhinovirus and adenovirus type 1 was seen in two children with respiratory syncytial virus. The other viruses included rhinovirus (three) adenovirus type 1 (two), adenovirus type 2 (one), adenovirus type 7 (two), parainfluenza virus type 3 (two), influenza A virus (three), and coxsackievirus B4 (two). Bacteriological studies (blood culture, bronchial secretions or both) were performed in 58 patients. Positive cultures were found in one of $45(2 \%)$ blood cultures and seven of $13(54 \%)$ bronchial secretion specimens obtained in five patients after tracheal intubation. The organisms isolated were Haemophilus influenza (three), Streptococcus pneumonia (one), Staphylococcus aureus (two), and Escherichia coli (three).

Table I gives the clinical details of the children studied. Controls were slightly older and taller than index cases. Fewer index cases had been breast fed.

TABLE I-Clinical details of index and control children. Results are means $\pm S D$

\begin{tabular}{|c|c|c|c|}
\hline & Index & Control & p Value \\
\hline $\begin{array}{l}\text { Sex: } \\
\text { Boys } \\
\text { Girls } \\
\text { Age (years) } \\
\text { Weight (kg) } \\
\text { Height (cm) } \\
\text { Gestation (wks) } \\
\text { Birth weight (kg) } \\
\text { Breast fed }\end{array}$ & $\begin{array}{c}123 \\
77 \\
7 \cdot 20 \pm 0 \cdot 44 \\
23 \cdot 1 \pm 3 \cdot 6 \\
119 \cdot 8 \pm 6 \cdot 1 \\
39 \cdot 4 \pm 2 \cdot 4 \\
3 \cdot 18 \pm 0 \cdot 64 \\
25\end{array}$ & $\begin{array}{c}123 \\
77 \\
7 \cdot 38 \pm 0 \cdot 44 \\
23 \cdot 4 \pm 3 \cdot 3 \\
121 \cdot 8 \pm 5 \cdot 1 \\
39 \cdot 7 \pm 1 \cdot 9 \\
3 \cdot 23 \pm 0 \cdot 50 \\
42\end{array}$ & $\begin{array}{c}<0.01^{*} \\
\text { NS }^{*} \\
<0.001^{*} \\
\text { NS }^{*} \\
\text { NS }^{*} \\
<0.05 \dagger\end{array}$ \\
\hline
\end{tabular}

*Paired $t$ test.

†McNemar's test.

Table II gives details of respiratory symptoms, medication, absence from school, general practitioner consultation for respiratory illnesses and also "established" bronchitis and asthma, which were diagnosed on the basis of replies to the questionnaire and the scrutiny of general practitioner records. Recurrent or established bronchitis is defined as four or more episodes of cough necessitating medical attention, and asthma as four or more episodes of wheezing during the year before follow-up study. Respiratory symptoms and established respiratory disorders were more common in index cases than. in controls.

We recorded also the occurrence of neonatal respiratory disorders and "chestiness" in association with the common exanthemata. Neonatal respiratory illnesses were documented in 14 index children and five controls (NS). No differences were noted in the proportion of children in whom whooping cough or chickenpox were diagnosed in childhood. Fifty-nine of the index children had "chestiness" during measles compared with 15 controls $(p<0.05)$. 
TABLE II-Details of respiratory symptoms, medication, absence from school, general practitioner consultation, and established bronchitis and asthma in index and control children

\begin{tabular}{|c|c|c|c|}
\hline & $\begin{array}{c}\text { Index } \\
(n=200)\end{array}$ & $\begin{array}{l}\text { Control } \\
(n=200)\end{array}$ & p Value \\
\hline $\begin{array}{l}\text { Tendency to cough: } \\
\text { At any time } \\
\text { In past year } \\
\text { Sputum } \\
\text { Colds going to chest }\end{array}$ & $\begin{array}{r}69 \\
34 \\
10 \\
105\end{array}$ & $\begin{array}{r}26 \\
11 \\
2 \\
41\end{array}$ & $\begin{array}{l}<0.01^{*} \\
<0.01^{*} \\
<0.05^{*} \\
<0.01^{*}\end{array}$ \\
\hline $\begin{array}{l}\text { Tendency to wheeze: } \\
\text { At any time } \\
\text { In past year }\end{array}$ & $\begin{array}{l}94 \\
21\end{array}$ & $\begin{array}{r}34 \\
2\end{array}$ & $\begin{array}{l}<0.01^{*} \\
<0.01^{*}\end{array}$ \\
\hline $\begin{array}{l}\text { Recurrent nasal blockage or } \\
\text { discharge } \\
\text { Difficulties in hearing } \\
\text { Tonsils removed } \\
\text { Adenoids removed } \\
\text { Medication in past year: } \\
\text { Antibiotics } \\
\text { Bronchodilators } \\
\text { Absence from school in past }\end{array}$ & $\begin{array}{l}70 \\
37 \\
19 \\
35 \\
91 \\
83 \\
22\end{array}$ & $\begin{array}{r}44 \\
21 \\
18 \\
25 \\
35 \\
31 \\
9\end{array}$ & $\begin{array}{l}<0.01^{*} \\
=0.05^{*} \\
\mathbf{N S}^{*} \\
\mathbf{N S}^{*} \\
<0.01^{*} \\
\mathbf{N S} \\
\mathbf{N S}^{*}\end{array}$ \\
\hline $\begin{array}{l}\text { Absence from school in past } \\
\text { year (wks) } \\
\text { No of GP consultations for }\end{array}$ & $1.9 \pm S D 3.7$ & $0 \cdot 8 \pm \mathrm{SD} 1 \cdot 3$ & $<0.001 \dagger$ \\
\hline $\begin{array}{l}\text { respiratory illnesses in past year } \\
\text { Established bronchitis } \\
\text { Established asthma }\end{array}$ & $\begin{array}{c}2 \cdot 1 \pm \underset{7}{\operatorname{SD}} 4 \cdot 8 \\
17\end{array}$ & $0.9 \pm \underset{1}{5}$ & $\begin{array}{l}<0.005^{\dagger} \\
\text { NS* }^{*} \\
<0.05^{*}\end{array}$ \\
\hline
\end{tabular}

*McNemar's test. †Wilcoxon test.

\section{SOCIAL AND FAMILY FACTORS}

Table III gives a comparison of social and family factors. More index children came from social classes IV and V. In the control group family size was smaller and the proportion of homes with central heating larger. No differences were found in the type of housing, the number of rooms per house, or the number of adults per household. The proportion of homes with pets was similar in both groups. Two-thirds of parents in both groups had smoked at some stage during their children's lives.

We compared the atopic background of index cases and their controls. A family history of asthma (first-degree relatives) was noted in 110 index cases and 90 controls (NS). There were, however, no discrepancies in matched pairs when personal or family history of eczema, hay fever, food allergy, and asthma were analysed.

TABLE III-Social and family factors in index and control children

\begin{tabular}{|c|c|c|c|}
\hline & $\begin{array}{c}\text { Index } \\
(\mathbf{n}=200)\end{array}$ & $\begin{array}{l}\text { Controls } \\
(n=200)\end{array}$ & p Value \\
\hline $\begin{array}{l}\text { Social class distribution: } \\
\text { I and II } \\
\text { III } \\
\text { IV and V } \\
\text { First-born } \\
\text { No of siblings } \\
\text { Both parents at home } \\
\text { Central heating } \\
\text { Own bedroom } \\
\text { Mother smoked at some stage } \\
\text { Father smoked at some stage } \\
\text { Mother's age at follow-up (years) } \\
\text { Father's age at follow-up (years) }\end{array}$ & $\begin{array}{c}30 \\
46 \\
124 \\
58 \\
1 \cdot 9 \pm 1 \cdot 8 \\
161 \\
89 \\
58 \\
142 \\
148 \\
32 \cdot 2 \pm \text { SD } 5 \cdot 3 \\
34 \cdot 9 \pm \text { SD } 6 \cdot 2\end{array}$ & $\begin{array}{c}43 \\
56 \\
100 \\
90 \\
1 \cdot 4 \pm 1 \cdot 0 \\
180 \\
114 \\
82 \\
132 \\
130 \\
33 \cdot 1 \pm \text { SD } 5 \cdot 1 \\
34 \cdot 9 \pm \text { SD } 6 \cdot 2\end{array}$ & $\begin{aligned} &< 0.05^{*} \\
&<0.01^{*} \\
&<0.001^{*} \\
& \text { NS* } \\
&=0.01^{*} \\
&<0.05^{*} \\
& \text { NS* } \\
& \text { NS* } \\
&<0.05^{*} \\
& \text { NS }\end{aligned}$ \\
\hline
\end{tabular}

${ }^{*}$ McNemar's test.

†Paired $t$ test.

\section{RESPIRATORY FUNCTION}

Results were expressed as percentage of predicted value for height, thereby eliminating effects caused by height differences. Table IV

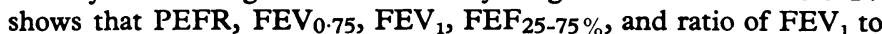
FVC were significantly lower in index cases than in controls. Mean $\mathbf{R}_{\mathrm{T}}$ was similar in both groups and within the normal range. ${ }^{23}$

Table $\mathrm{V}$ gives results of exercise testing. ${ }^{24}$ The rise in PEFR during exercise and exercise lability were comparable in index and control subjects. After exercise a reduction of $>10 \%$ of the resting value was seen in 69 index children and 46 controls $(p<0.05)$. A fall in PEFR $>15 \%$ of resting value ${ }^{25}$ was observed in 29 index children and 16 controls $(p=0.05)$. This included all children clinically designated as asthmatic.

Analysis of MEFV curves breathing air followed by $80 \%$ oxygen and $20 \%$ helium showed no differences between index and control groups. This investigation was limited to a subgroup of patients
TABLE IV-Results of respiratory function tests in 197 matched pairs

\begin{tabular}{lccccc}
\hline & \multicolumn{2}{c}{ Mean value } & \multicolumn{3}{c}{$\begin{array}{c}\text { Standard } \\
\text { error of }\end{array}$} \\
\cline { 2 - 3 } & Index & Control & $\begin{array}{c}\text { Mean } \\
\text { difference }\end{array}$ & difference & p Value \\
\hline PEFR (\% predicted) & 97.3 & 100.9 & -3.64 & 1.59 & $<0.05$ \\
FEV $_{0.75}$ (\% predicted) & 88.7 & 92.8 & -4.14 & 1.31 & $<0.005$ \\
FEV $_{1}$ (\% predicted) & 91.3 & 95.0 & -3.70 & 1.24 & $<0.005$ \\
FVC (\% predicted) $_{\text {FEF }_{25-75 \%} \text { (predicted) }}$ & 86.3 & 87.1 & -0.73 & 1.24 & $\mathrm{NS}$ \\
FEV $_{1}: \mathrm{FVC}$ & 91.8 & 102.3 & -10.58 & 3.08 & $<0.001$ \\
$\mathrm{R}_{\mathrm{T}}(\mathrm{kPa} / \mathrm{l} / \mathrm{s})$ & 0.88 & 0.91 & -0.03 & 0.008 & $<0.001$ \\
\hline
\end{tabular}

PEFR = Peak expiratory flow rate. $\mathrm{FEV}_{0.75}=$ Forced expiratory volume in $0.75 \mathrm{~s}$ $\mathrm{FEV}_{1}=$ Forced expiratory volume in $1 \mathrm{~s}$. FVC $=$ Forced vital capacity. $\mathrm{FEF}_{25-75} \%=$ Forced expiratory flow in middle half of expired volume. $\mathbf{R}_{\mathrm{T}}=$ Total respiratory resistance.

TABLE $\mathrm{V}-$ Effect of exercise ${ }^{24}$ on respiratory function

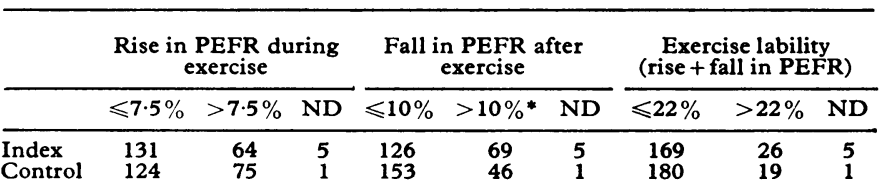

*Index $v$ controls $\mathrm{p}<0.05$

PEFR = Peak expiratory flow rate.

admitted during the third winter period. Conventional tests of ventilatory function, however, revealed differences in FEV $_{0.75}$ $(\mathrm{p}<0.05)$ and $\mathrm{FEV}_{1}(\mathrm{p}<0.05)$

COMPARISON OF INDEX CHILDREN WITH AND WITHOUT RESPIRATORY SYNCYTIAL VIRUS

Comparisons were made between those index children who had had respiratory syncytial virus (group 1) and those who had not (group 2) (100 in each group). No significant difference was found in the age at which the index illness occurred ( 4.3 months in both groups) or in the proportion who were breast fed (seven in group 1 and five in group 2). Social class distribution and personal or family histories of atopic disorders were similar in both subgroups. Recurrent wheeze was reported in 49 of group 1 and 45 of group 2 and established asthma in six and 11 respectively.

At follow-up the mean height of children in group 1 was $119.7 \mathrm{~cm}$, almost identical to that of children in group $2(119.8 \mathrm{~cm})$. Mean weight was also similar (group $123.2 \mathrm{~kg}$, group $223.0 \mathrm{~kg}$ ). No differences were observed in results of tests of ventilatory function and total respiratory resistance or in the response to exercise.

\section{Discussion}

These results show that children who have suffered acute lower respiratory tract infection in infancy severe enough to merit hospital treatment have an increase in respiratory symptoms, established bronchitis, and asthma; impairment of ventilatory function; and increased bronchial hyperreactivity when compared with case controls seven years later. This might reflect a "genetic predisposition," increasing susceptibility to both respiratory infection and the subsequent development of respiratory symptoms and illnesses. In one carefully planned study, ${ }^{26}$ however, children who suffered chest infection in infancy were shown to have normal respiratory function (at birth) compared with those who escaped subsequent respiratory illnesses. By the age of 1 differences in crying PEFR were apparent, and it is tempting to ascribe these to the direct effects of infection on airways or lung paranchyma.

On the other hand, host differences may have operated from the outset, perhaps an increased susceptibility to virus infection from birth. Frick et $a l^{27}$ suggested that virus infection may contribute to allergic sensitisation in susceptible infants, with an increase in subsequent cough and wheeze on that basis. More recent studies ${ }^{28}{ }^{29}$ on nasopharyngeal secretions in infants after 
respiratory syncytial virus infection suggest that production of IgE and the subsequent release of chemical mediators of bronchospasm may contribute to the pathogenesis of acute illnesses due to respiratory syncytial virus and may also explain the subsequent tendency to recurrent wheezing. This may be particularly relevant in acute bronchiolitis.

Our studies suggest that atopic characteristics were similar in index and control groups. Skin-prick testing, which would have provided a more sensitive guide to atopy was omitted from the study protocol, as it was considered unjustified, especially in symptom-free control children. Our finding must therefore be interpreted with caution. A study of infants admitted to hospital with acute bronchiolitis ${ }^{30}$ showed an increased number of positive skin-test results to common allergens compared with controls, suggesting that atopic state was relevant from the outset-at least in acute bronchiolitis.

Though the tendency to cough and wheeze increased after index illnesses in our study, these symptoms diminished by the age of 7 , which agrees with previous findings. ${ }^{31}$ The prevalence of established bronchitis and asthma was also higher in index cases than in controls. The discrepancy between the prevalence of these conditions and that of bronchial hyperreactivity suggests that our criteria for diagnosing asthma, for example, were too stringent. Not all children with bronchial hyperreactivity wheezed recurrently in the year before study, whereas all those with significant clinical asthma had hyperreactive airways. We may therefore have excluded some mildly affected children. Looked at slightly differently, 22 index cases and 9 controls had been treated with bronchodilator drugs at some time during the year before the study: none of these cases had more than mild symptoms at that time. It seems, therefore, that about $10 \%$ of index cases had asthma at review.

Owing to the design of the study control children were not studied until after the index cases had been traced and assessed. On average they were three months older than index children. This does not fully explain the observed differences in height between index cases and controls even though we had attempted to control this variable. This difference was more probably related to the effect of increased respiratory problems or to social factors.

It might be argued that social and environmental factors were the main determinants of outcome (quite apart from height) in our study. More control children came from higher social classes and from slightly smaller families. More were first-born so that there was less likelihood of acquiring infection from older siblings. These social differences may not be as great as appears at first sight. The social-class designation based on the Registrar General's criteria gives no extra information on parental education, standards of maternal care, family size, or housing conditions, which are perhaps more sensitive social indicators than the occupation of the head of the household.

Housing standards were similar in the two groups as were the number of resident adults and their smoking habits. To a large extent our choice of controls from the same class and same school as index children eliminated socioeconomic and environmental differences between the two groups and it seems unlikely that social class alone was the main determinant of the difference in outcome for index and control children. The difficulty of assessing the effects of social variables is further highlighted in a study ${ }^{31}$ for children with proved respiratory syncytial virus bronchiolitis in infancy who were found to have diminished respiratory function when compared with controls matched for age, sex, and social class. Despite social class comparability children who had had bronchiolitis came from "poorer" environmental backgrounds. This led to the suggestion that environmental factors provided a link between respiratory infection in infancy and subsequent respiratory illness in childhood or even adult life.

Abnormalities of lung function have been shown ${ }^{32}$ in a high proportion of children with a history of bronchiolitis in infancy but without subsequent respiratory symptoms 10 years later. These were attributed to residual effects on small airways.
We have shown abnormalities in respiratory functions seven years after lower respiratory tract infection in infancy that are not easily explained on any basis other than the occurrence of severe infection in infancy. Most infections were caused by viruses and our failure to find the difference in outcome for those who had had respiratory syncytial virus and those who had not is perhaps not surprising. During the study period our isolation rate for respiratory syncytial virus in such cases increased from $50 \%$ in the first year to about $70 \%$ in the third, as methods of collection, transport, and laboratory techniques improved. It seems likely that respiratory syncytial virus was the causative agent in an appreciable number of cases in which the virus was not isolated despite our lack of confirmation and that this explains our findings.

Alternatively, the outcome may not be influenced by the nature of the causative agent. Though available evidence is not conclusive infection of the respiratory tract during a vulnerable period of lung growth in infancy may cause direct injury or induce changes that lead to impairment of lung function. Whether such children ultimately outgrow their respiratory symptoms with full functional recovery or whether they become more vulnerable to the effects of environmental factors such as smoking and atmospheric pollution as they grow older is not known. More longitudinal studies into adult life are indicated to trace the clinical course of chest infections in early childhood.

This study was supported by a generous grant from the Chest, Heart and Stroke Association. We thank Dr J M Inglis, who provided the virological service; Dr $M$ Fulton for help in preparing the questionnaire; Mr W Adams and Mrs W Hepburn of the Medical Computing and Statistics Department, University of Edinburgh; and Miss $S$ Mangal, who typed the manuscript. We also thank general practitioners for their co-operation; the technical staff of the respiratory function laboratory, Royal Hospital for Sick Children, Edinburgh; and all the children and parents who participated in the study.

\section{References}

${ }^{1}$ Colley JRT, Holland WW. Social and environmental factors in respiratory disease. A preliminary report. Arch Environ Health 1967;14:157-61.

${ }^{2}$ Leeder SR, Corkhill R, Irwig LM, Holland WW, Colley JRT. Influence of family factors on the incidence of lower respiratory tract illness during the first year of life. Br $\mathcal{F}$ Prev Soc Med 1976;30:203-12.

3 Yarnell JWG, St Leger AS. Housing conditions, respiratory illness and lung function in children in South Wales. Br F Prev Soc Med 1977;31 183-8.

${ }^{4}$ Douglas JWB, Waller RE. Air pollution and respiratory infection in children. Br F Prev Soc Med 1966;20:1-8

${ }^{5}$ Lunn JE, Knowelden J, Handyside AJ. Patterns of respiratory illness in Sheffield infant schoolchildren. Br F Prev Soc Med 1967;21:7-16.

6 Lunn JE, Knowelden J, Roe RW. Patterns of respiratory illness in Sheffield junior schoolchildren. A follow-up study. Br f Prev Soc Med $1970 ; 24: 223-8$

7 Norman-Taylor W, Dickinson VA. Dangers for children in smoking families. Community Med 1972;128:32-3.

${ }^{8}$ Harlap S, Davies AM. Infant admissions to hospital and maternal smoking. Lancet 1974 ; i:529-32.

9 Fergusson DM, Horwood LJ, Shannon FT. Parental smoking and respiratory illness in infancy. Arch Dis Child 1980;55:358-61.

10 Colley JRT, Douglas JWB, Reid DD. Respiratory disease in young adults : influence of early childhood lower respiratory tract illness, social class, air pollution and smoking. $\mathrm{Br}$ Med f 1973;iii:195-8.

11 Kiernan KE, Colley JRT, Douglas JWB, Reid DD. Chronic cough in young adults in relation to smoking habits, childhood environment and chest illness. Respiration $1976 ; 33: 236-44$.

12 Burrows B, Knudson RJ, Lebowitz MD. The relationship of childhood respiratory illness to adult obstructive airway disease. Am Rev Respir Dis 1977;115:751-60.

13 Polmar SH, Robinson LD, Minnefor AB. Immunoglobulin E in bronchiolitis. Pediatrics 1972;50:279-84.

14 Eisen AH, Bacal HL. The relationship of acute bronchiolitis to bronchial asthma. A 4-to-14-year follow-up. Pediatrics 1963;31:859-61.

${ }^{15}$ Zweiman B, Schoenwetter WF, Pappano JE, Tempest B, Hildreth EA. Patterns of allergic respiratory disease in children with a past history of bronchiolitis. F Allergy Clin Immunol 1971;48:283-9.

${ }^{16}$ Rooney JC, Williams HE. The relationship between proved viral bronchiolitis and subsequent wheezing. $\mathcal{f}$ Pediatr 1971;79:744-7.

17 Clarke SKR, Gardner PS, Poole PM, Simpson H, Tobin J O'H. Respiratory syncytial virus infection: admissions to hospital in industrial, urban 
and rural areas. Report to the Medical Research Council Subcommittee on Respiratory Syncytial Virus Vaccines. Br Med F 1978;ii:796-8.

18 Goldman M, Knudson RJ, Mead J, Peterson N, Schwaber JR, Wohl ME. A simplified measurement of respiratory resistance by forced oscillation. f Appl Physiol 1970;28:113-6.

19 Wright BM, McKerrow CB. Maximum forced expiratory flow rate as a measure of ventilatory capacity. With a description of a new portable instrument for measuring it. Br Med F 1959;ii:1041-7.

20 Cotes JE. Lung function: assessment and application in medicine. Oxford: Blackwell Scientific Publications, 1979.

${ }^{21}$ Mok JYQ, Waugh PR, Simpson H. Mycoplasma pneumoniae infection. A follow-up study of 50 children with respiratory illnesses. Arch Dis Child 1979;54:506-11.

22 McNemar Q. Note on sampling error of the differences between correlated proportions or percentages. Psychometrika $1947 ; 12: 153-7$.

${ }^{23}$ Cogswell JJ. Forced oscillation technique for determination of resistance to breathing in children. Arch Dis Child 1973;48:259-66.

24 Silverman M, Anderson SD. Standardisation of exercise tests in asthmatic children. Arch Dis Child 1972;47:882-9.

25 Kjellman B. Ventilatory capacity and efficiency after exercise in healthy and asthmatic children. Scand $\mathcal{F}$ Respir Dis 1969;50:41.

${ }_{26}$ Colley JRT, Holland WW, Leeder SR, Corkhill RT. Respiratory function of infants in relation to subsequent respiratory disease: an epidemiological study. Bull Eur Physiopathol Respir 1976;12:651-7.

${ }^{27}$ Frick OL, German DF, Mills J. Development of allergy in children. I. Association with virus infections. $\mathcal{F}$ Allergy Clin Immunol 1979;63:22841.

${ }^{28}$ Henderson FW, Collier AM, Clyde WA, Denny FW. Respiratory syncytial virus infections, reinfections and immunity in young children. $N$ Engl f Med 1979;300:530-5.

${ }^{29}$ Welliver RC, Wong DT, Sun M, Middleton E, Vaughan RS, Ogra PO. The development of respiratory syncytial virus-specific IgE and the release of histamine in nasopharyngeal secretions after infection. $N \mathrm{Engl}$ 7 Med $1981 ; 305: 841-6$

${ }^{30}$ Laing I, Riedel F, Yap PL, Simpson H. Atopy predisposing to acute bronchiolitis during an epidemic of respiratory syncytial virus. $\mathrm{Br} \mathrm{Med} \mathcal{F}$ $1982 ; 284: 1070-2$

31 Sims DG, Downham MAPS, Gardner PS, Webb JKG, Weightman D. Study of 8-year-old children with a history of respiratory syncytial virus bronchiolitis in infancy. $B r$ Med $\mathcal{f} 1978 ; \mathrm{i}: 11-4$.

32 Kattan M, Keens TG, Lapierre JG, et al. Pulmonary function abnormalities in symptom-free children after bronchiolitis. Pediatrics 1977;59: 683-8.

(Accepted 4 fune 1982)

\title{
Penicillinase-producing Neisseria gonorrhoeae in Great Britain, 1977-81: alarming increase in incidence and recent development of endemic transmission
}

\author{
J ALLEN MCCUTCHAN, MICHAEL W ADLER, JOHN R H BERRIE
}

\begin{abstract}
Since penicillinase-producing Neisseria gonorrhoeae appeared five years ago in West Africa and South-east Asia reported cases have doubled annually in Great Britain, primarily as a result of increasing importation. Importation of penicillinase-producing Neisseria gonorrhoeae has increased exponentially because dramatic expansion of these strains in their regions of origin has led to increasing infection of male air travellers. From 1977 to 1980 infections acquired in Great Britain played only a minor part in the exponential increase. During 1981 the number of indigenous cases increased much more rapidly than imported cases, indicating that these strains have become truly endemic in Great Britain.

Currently, identification of patients at high risk and initial treatment with penicillinase-resistant antibiotics offers the best hope of containing the strains. The emergence and rapid spread of penicillinase-producing Neisseria gonorrhoeae shows the international consequences of the abuse of antibiotics.
\end{abstract}

\footnotetext{
Academic Department of Genito-Urinary Medicine, Middlesex Hospital Medical School, London W1N 8AA

J ALLEN MCCUTCHAN, MD, MSC, research associate (scholar of the Milbank Memorial Fund, New York)

MICHAEL W ADLER, MD, MRCP, professor

Communicable Disease Surveillance Centre, Public Health Laboratory Service, Colindale, London NW9

JOHN R H BERRIE, MB, FFCM, senior medical officer
}

\section{Introduction}

In 1976 strains of Neisseria gonorrhoeae appeared in West Africa and South-east Asia containing plasmids which coded for penicillin-splitting enzymes ( $\beta$-lactamases) similar to those found in Escherichia coli and Haemophilus influenzae. Their ability to spread internationally was illustrated by initial case reports from London ${ }^{1}$ and California ${ }^{2}$ and by a large epidemic in Liverpool. ${ }^{3}$ In a few years they were well established in their regions of origin and had spread worldwide. ${ }^{4}$ This continuing process threatens to render ineffective the current treatment for gonorrhoea with penicillins. Effective, alternative regimens are either more expensive or more complicated. Techniques to control the spread of these strains are urgently needed but require an understanding of how they are spreading. Great Britain is a uniquely suitable place for studying this process for three reasons. Firstly, the system of specialised, hospital-based clinics for sexually transmitted diseases with full microbiological support ensures that most cases are detected. Secondly, a voluntary system of reporting has allowed the Communicable Diseases Surveillance Centre to monitor the epidemiology of the disease since 1977. Finally, direct airline connections from both Asia and Africa have resulted in importation of the strains originating in both endemic areas. Thus, the epidemiology of these two types of penicillinase-producing Neisseria gonorrhoeae can be compared under similar conditions of importation, detection, and reporting. We have analysed the epidemiology of the disease in Great Britain based on data reported to the Communicable Diseases Surveillance Centre and have provided practical advice on their detection and treatment.

\section{Methods}

A reporting system for penicillinase-producing Neisseria gonorrhoeae in the United Kingdom was started in 1977 by the Communicable Disease Surveillance Centre, Colindale. Clinical data (age, sex, and 